\title{
Nanoparticles: A Promising Treatment for Herpes Simplex Virus Type-1 Infections
}

\author{
Nanopartiküller: Herpes Simpleks Virüs Tip-1 Enfeksiyonları için Umut Veren Bir Tedavi
}

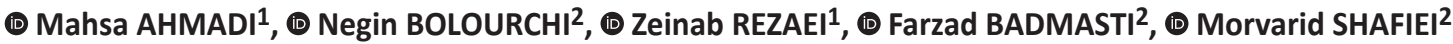 \\ ${ }^{1}$ Alzahra University Faculty of Biological Sciences, Department of Microbiology, Tehran, Iran \\ 2 Pasteur Institute of Iran, Department of Bacteriology, Tehran, Iran
}

\section{Abstract}

Herpes simplex virus type-1 (HSV-1) is a prevalent pathogen that causes various outcomes from oral and facial lesions to fatal encephalitis and herpetic keratitis. Acyclovir (ACV) is a current treatment option for HSV-1 infection. However, considering the emergence of ACV-resistant HSV-1 and the detrimental side effects of prolonged administration of ACV such as acute kidney injury, the development of novel antiviral therapeutic agents and new drug delivery systems appear indispensable. With the advent of nanotechnology, nanoparticles (NPs) have attracted great attention as antimicrobial agents and drug carriers because of their unique physical and chemical properties. This review focused on the antiviral activity of NPs against HSV-1 infection and their application in the delivery of ACV.

Keywords: Antiviral therapy, HSV-1 infection, nanoparticles, nanocarriers, acyclovir

\section{Öz}

Herpes simpleks virüs tip-1 (HSV-1), ağız ve yüz lezyonlarından ölümcül ensefalite ve herpetik keratite kadar çeşitli sonuçlara neden olan yaygın bir patojendir. Asiklovir (ACV), HSV-1 enfeksiyonunun tedavisinde güncel bir seçenektir. Bununla birlikte, ACV-dirençli HSV-1'in ortaya çıkışı ve akut böbrek hasarı gibi uzun süreli ACV uygulamasının zararlı yan etkileri göz önüne alındığında, yeni antiviral terapötik ajanların ve yeni ilaç dağıtım sistemlerinin geliştirilmesi vazgeçilmez görünmektedir. Nanoteknolojinin gelişmesiyle birlikte nanopartiküller (NP), benzersiz fiziksel ve kimyasal özelliklerinden dolayı antimikrobiyal ajanlar ve ilaç taşıyıcıları olarak büyük ilgi görmüştür. Bu derlemede, NP'lerin HSV-1'e karşı antiviral aktivitesine ve bunların ACV dağıtımındaki uygulamalarına odaklandık.

Anahtar Kelimeler: Antiviral tedavi, HSV-1 enfeksiyonu, nanopartiküller, nanotaşıyıcılar, asiklovir

\section{Introduction}

Herpes simplex virus type-1 (HSV-1) is a double-stranded DNA virus belonging to Herpesviridae family and Alphaherpesvirinae subfamily. Herpes simplex virus type-1 has approximately 152 kbp encoding genes and more than 80 various open-reading frames that are surrounded by an icosahedral capsid. The capsid is encased by a bilayer lipid envelope containing $\geq 12$ different viral proteins. Some of these proteins interact with host cell surface receptors and are responsible for viral initial attachment to the host cell. Viral envelope glycoprotein C $(\mathrm{gC})$ and glycoprotein B (gB) mediate the initial attachment by interacting with heparan sulfate proteoglycans (HS GP). Following the conformational changes, glycoprotein $D(g D)$ interacts with one of three potential entry receptors, namely, herpes virus entry mediator, a member of the tumor necrosis factor receptor family; Nectin-1, a member of the immunoglobulin superfamily; and 3-0 sulfated HS (3-OS-HS), a member of HS family. $g B, g H$, and $g \mathrm{~L}$ facilitate the binding of $g \mathrm{D}$ to the cell receptors and the fusion process ${ }^{[1-4]}$.

Cite this article as: Ahmadi M, Bolourchi N, Rezaei Z, Badmasti F, Shafiei M. Nanoparticles: A Promising Treatment for Herpes Simplex Virus Type-1 Infections. Mediterr J Infect Microb Antimicrob. 2021;10:56. 
Herpes simplex virus type- 1 is one of the most prevalent pathogens that are often acquired during childhood and remain latent in nerve cells. Herpes simplex virus type- 1 is a neurotropic pathogen with a wide diversity of clinical manifestations ranging from harmless skin infections such as ulcerative and vesicular oral/facial lesions to harmful central nervous system infections. In adults, the serious clinical outcomes of HSV-1 vary from encephalitis with long-term consequences to herpetic keratitis leading to blindness.

Acyclovir (ACV) also known as acycloguanosine was discovered in 1977-1978, and after more than 40 years, ACV and its pro-drugs are still current therapeutic options against HSV-1 infections and reactivation. However, ACV has several limitations including low absorption and bioavailability (15-20\%), short elimination half-life of 2.5-3 hours post-administration requiring frequent and high drug usage, and side effects. Besides, the drug-resistant strains of HSV-1 emerge among high-risk groups such as patients with immunocompromised status and patients who had transplantation. Hence, the development of safer and more effective alternatives appears crucial ${ }^{[5-8]}$.

Nanotechnology provides new methods in the era of medicine. Nanoparticles (NPs) are a wide class of materials and are divided into three main categories depending on their chemical properties: inorganic NPs, organic NPs, and carbon-based NPs. Two basic approaches are employed to prepare NPs: 1) top-down approach, where synthesis is initialized with the bulk counterpart that leaches out systematically bit-after-bit leading to the generation of fine NPs, and 2) bottom-up approach, which involves the coalescence or assembly of atoms and molecules to generate a diverse range of NPs. In general, NP synthesis methods can be divided into three categories including physical, chemical, and biological methods, and each of these approaches has several advantages and drawbacks (Table 1). In physical methods, mechanical pressure, high-energy radiations, thermal energy, or electrical energy that causes material abrasion, melting, evaporation, or condensation are applied to generate NPs based on the top-down approach. Highenergy ball milling, laser ablation, electro-spraying, inert gas condensation, physical vapor deposition, laser pyrolysis, flash spray pyrolysis, and melt mixing are some of the most commonly utilized physical technologies to produce NPs. The chemical synthesis of NPs follows the bottom-up approach. Nucleation mainly involves the use of water-soluble cation as a precursor to trigger their reduction to metal monomers. Particles that assembled a cluster of reduced metal atoms automatically stop the growth by using a reducing or capping agent. The particles reach a certain thermally stable size. Nanomaterials are synthesized by the interaction of atoms and smaller molecules. Various chemical synthesis techniques include the sol-gel process, pyrolysis, chemical vapor deposition, microemulsion, hydrothermal, polyol synthesis, and plasma-enhanced chemical vapor. Biological or bioassisted methods employ biological systems such as bacteria, fungi, viruses, yeast, actinomycetes, and plant extracts for the synthesis of NPs. Bio-assisted methods can be divided into three categories, including biogenic synthesis (using microorganisms), biogenic synthesis (using biomolecules as

Table 1. Advantages and disadvantages of the synthesis procedures of nanoparticles ${ }^{[11]}$

\begin{tabular}{|c|c|c|}
\hline NP synthesis methods & Advantages & Disadvantages \\
\hline Physical methods & $\begin{array}{l}\text { - High speed } \\
\text { - Non-use of toxic chemicals } \\
\text { - Purity } \\
\text { - Uniform size and shape }\end{array}$ & $\begin{array}{l}\text { - Less productivity } \\
\text { - High amounts of waste } \\
\text { - High dilution } \\
\text { - Difficult size and shape tunability } \\
\text { - Less possibility in stability } \\
\text { - Less economical }\end{array}$ \\
\hline Chemical methods & $\begin{array}{l}\text { - Cost effective } \\
\text { - High versatility in surface chemistry } \\
\text { - Easy functionalization } \\
\text { - High yield } \\
\text { - Size controlled } \\
\text { - Thermally stable } \\
\text { - Reduced dispersity }\end{array}$ & $\begin{array}{l}\text { - Low purity } \\
\text { - Use of toxic chemicals and organic solvents } \\
\text { - Hazardous to humans and the environment }\end{array}$ \\
\hline Biological methods & $\begin{array}{l}\text { - Nanoparticles are soluble, biocompatible, and } \\
\text { sustainable } \\
\text { - Cost effective } \\
\text { - Eco-friendly }\end{array}$ & $\begin{array}{l}\text { - Hard-to-control shape, size, crystal growth, stability, and } \\
\text { aggregation } \\
\text { - Possible endotoxin } \\
\text { - Time-consuming }\end{array}$ \\
\hline
\end{tabular}


templates), and biogenic synthesis (using plant extracts). In these cases, reducing agents or other constituents present in the cells act as stabilizing and capping agents; thus, there is no need to add capping and stabilizing agents from the outside. Various factors such as $\mathrm{pH}$, temperature, and reaction time control the synthesis and stabilization of NPs synthesized by biological entities. Nanoparticles have attracted great attention because of their specific physical and chemical properties, including smaller size, higher quantity of surface atoms, and high surface-to-volume ratios. Therefore, NPs have various applications in drug designing and diagnostic medicine ${ }^{[9-12]}$. This review will discuss the antiviral activity of NPs against HSV-1 infections (Table 2) and the application of NPs in the delivery of ACV.

\section{Inorganic Anti-Herpes Simplex Virus Type-1 Nanoparticles}

Inorganic NPs are classified into two main categories: metal and metal oxide NPs. Metal NPs interfere with viral replication or block viral entry at the subcellular level. Metal NPs particularly silver and gold NPs possess substantial antiviral activity against viruses. Other metal NPs such as copper, zinc, iron, and selenium NPs also show antiviral potential. The antiviral activity of metal NPs varies based on their size, shape, metal ions, and capping agents. Capped metal NPs enhance the interaction between host cells and viruses and consequently exhibit higher antiviral activity than naked metal NPs. Recently, several studies have reported the anti-HSV-1 effect of metal NPs, and these are discussed below $w^{[9,11,13]}$.

\subsection{Silver-based NPs}

In 2012, Mohammed Fayaz et al. ${ }^{[14]}$ investigated the antiviral effect of silver NPs (AgNPs) coated by polyurethane condom (PUC) against HSV-1 infection. Different titers of HSV-1 were incubated with PUC-coated AgNPs and non-coated ones for 30 min. Then, the medium was utilized to infect Vero-E6 cells. The results indicated that non-coated NPs have no inhibitory effect on HSV-1. Comparatively, the viral infection was significantly reduced by the incubation of HSV-1 with PUC-coated AgNPs. Additionally, no cytopathic effects were observed in Vero-E6 cells on day 2 post-incubation.

Gaikwad et al. ${ }^{[15]}$ in 2013 evaluated the anti-HSV-1 potential of biologically produced AgNPs. They utilized five fungal species including Alternaria sp., Fusarium oxysporum, Curvularia sp., C. indicum, and Phoma sp. to synthesize AgNPs. Virus pretreatment, cell pretreatment, cell post-treatment, and cotreatment assays were conducted to evaluate the antiviral effect of AgNPs on different stages of virus infection. Indeed, the virus pretreatment assay was conducted to investigate the virucidal activity of AgNPs and the possibility of interference with HSV particles and irreversible inhibition of virus penetration. Cell pretreatment assay was carried out to explore the potential of AgNP interference with early viral penetration and their inhibitory effect on virus attachment to the host cells. In addition, the cell post-treatment assay was performed to evaluate the inhibitory effects of AgNPs on HSV-1 replication and thus the prediction of the postentry effect of AgNPs on infected cells. The cotreatment assay, in which AgNPs and viruses were concomitantly added to the cell cultures, was used to investigate the possibility of the direct inhibition of viral particles by AgNPs during and after viral adsorption. The results of the cotreatment assay and cell post-treatment assay demonstrated that AgNPs produced by Alternaria sp. (7-20 nm) and Phoma sp. (7-20 $\mathrm{nm}$ ) had no inhibitory effect on HSV-1 infection. By contrast, AgNPs produced by F. oxysporum (4-13 nm), Curvularia sp. (10-31 nm), and C. indicum (5-23 nm) exhibited remarkable antiviral activity against HSV-1 infection. Furthermore, the results of the virus pretreatment assay revealed that AgNPs produced by F. oxysporum, Curvularia sp., and $C$. indicum reduced HSV-1 infection. By contrast, the result of the cell pretreatment assay illustrated that none of the AgNPs are efficient in reducing viral infection. Gaikwad et al. ${ }^{[15]}$ concluded that AgNPs do not block receptor sites and thus do not prevent virus entry while they can inactivate HSV1 because they interfere with viral replication at the postentry phase ${ }^{[16]}$.

In 2017, Ramadan et al. ${ }^{[17]}$ evaluated the antiviral properties of AgNPs against HSV-1 infection. They used aqueous extracts of M. alternifolia leaves for green synthesis of AgNPs (11.56 $\mathrm{nm})$. The results showed the inhibitory activities of greenly synthesized AgNPs against HSV-1 infection.

In 2018, Szymańska et al. ${ }^{[18]}$ investigated the effect of tannic acid (TA)/silver NP-based hydrogel. The results demonstrated that TA-AgNP-based hydrogel prevented viral attachment, penetration, and post-infection spread and thus had the considerable capability to inhibit HSV-1 infection. Szymańska et al. ${ }^{[18]}$ suggested that HSV-1 inactivation might be caused by a direct interaction between NPs and viral proteins or envelopes. The results showed higher affinity of TA-AgNPs to $\mathrm{gC}$ which is important in the attachment of HSV-1 that can inhibit viral attachment. In addition, the profusion domain of HSV-1 $\mathrm{gD}$ is a proline-rich region that is essential for virus entry. TA-AgNP-based hydrogel can interact with prolinerich proteins and consequently inhibit viral penetration. Furthermore, the authors confirmed that TA-AgNP-based hydrogel can significantly prevent the cell-to-cell spread of HSV-1.

In 2019, Haggag et al. ${ }^{[19]}$ utilized the aqueous and hexane extracts of Lampranthus coccineus and Malephora lutea for the synthesis of AgNPs. The results showed that AgNPs produced 
Table 2. Characteristics of anti-Herpes simplex virus type-1 nanoparticles

\begin{tabular}{|c|c|c|c|c|c|}
\hline First author & $\begin{array}{l}\text { Synthesis } \\
\text { mechanism }\end{array}$ & Nanoparticle type & Nanoparticle size (nm) & Nanoparticle coating & Antiviral mechanism \\
\hline $\begin{array}{l}\text { Mohammed Fayaz } \\
\text { et al. } 2012^{[14]}\end{array}$ & $\begin{array}{l}\text { Chemical } \\
\text { method }\end{array}$ & AgNPs & $30-60$ & $\begin{array}{l}\text { Polyurethane condom } \\
\text { coating }\end{array}$ & Not mentioned \\
\hline $\begin{array}{l}\text { Gaikwad et al. } \\
2013^{[15]}\end{array}$ & $\begin{array}{l}\text { Biological } \\
\text { method }\end{array}$ & AgNPs & $\begin{array}{l}\text { 1. } 7-20 \\
\text { 2. } 7-20 \\
\text { 3. 4-13 } \\
\text { 4. 10-31 } \\
\text { 5. 5-23 }\end{array}$ & Naked & $\begin{array}{l}\text { Interference with viral } \\
\text { replication at the post-entry } \\
\text { phase }\end{array}$ \\
\hline $\begin{array}{l}\text { Ramadan et al. } \\
2017^{[17]}\end{array}$ & $\begin{array}{l}\text { Biological } \\
\text { method }\end{array}$ & AgNPs & 11.56 & $\begin{array}{l}\text { M. alternifolia aqueous } \\
\text { extract coating }\end{array}$ & Not mentioned \\
\hline $\begin{array}{l}\text { Szymańska et al. } \\
2018^{[18]}\end{array}$ & $\begin{array}{l}\text { Chemical } \\
\text { method }\end{array}$ & TA-AgNPs & $33 \pm 13$ & Naked & $\begin{array}{l}\text { Prevent viral attachment, } \\
\text { penetration, and cell-to-cell } \\
\text { spread }\end{array}$ \\
\hline $\begin{array}{l}\text { Haggag et al. } \\
2019^{[19]}\end{array}$ & $\begin{array}{l}\text { Biological } \\
\text { method }\end{array}$ & AgNPs & $\begin{array}{l}\text { 1. } 10.12-27.89 \\
\text { 2. } 8.91-14.48\end{array}$ & Naked & $\begin{array}{l}\text { Block the viral penetration } \\
\text { and interfere with the viral } \\
\text { replication }\end{array}$ \\
\hline $\begin{array}{l}\text { Aridass et al. } \\
2019^{[7]}\end{array}$ & $\begin{array}{l}\text { Biological } \\
\text { method }\end{array}$ & AgNPs & Not mentioned & Naked & Not mentioned \\
\hline $\begin{array}{l}\text { El-Sheekh et al. } \\
2020^{[20]}\end{array}$ & $\begin{array}{l}\text { Biological } \\
\text { method }\end{array}$ & AgNPs & $14.42-48.97$ & Naked & Inhibit viral replication \\
\hline $\begin{array}{l}\text { Baram-Pinto et al. } \\
2010^{[3]}\end{array}$ & $\begin{array}{l}\text { Chemical } \\
\text { method }\end{array}$ & AuNPs & 4 & $\begin{array}{l}\text { Mercaptoethanolsulfonate } \\
\text { coating }\end{array}$ & $\begin{array}{l}\text { Block viral attachment and } \\
\text { cell-to-cell spread }\end{array}$ \\
\hline $\begin{array}{l}\text { Halder et al. } \\
2018^{[21]}\end{array}$ & $\begin{array}{l}\text { Chemical } \\
\text { method }\end{array}$ & $\begin{array}{l}\text { Monodispersed } \\
\text { AuNPs }\end{array}$ & $7.86 \pm 3.3$ & Naked & Block viral attachment \\
\hline $\begin{array}{l}\text { Aridass et al. } \\
2019^{[7]}\end{array}$ & $\begin{array}{l}\text { Biological } \\
\text { method }\end{array}$ & AuNPs & Not mentioned & Naked & Not mentioned \\
\hline $\begin{array}{l}\text { El-Sheekh et al. } \\
2020^{[20]}\end{array}$ & $\begin{array}{l}\text { Biological } \\
\text { method }\end{array}$ & AuNPs & $15.60-77.13$ & Naked & Inhibit viral replication \\
\hline I et al. $2020^{[22]}$ & $\begin{array}{l}\text { Chemical } \\
\text { method }\end{array}$ & AuNPs & Not mentioned & Naked & Inhibit viral entry \\
\hline $\begin{array}{l}\text { Mishra et al. } \\
2011^{[23]}\end{array}$ & $\begin{array}{l}\text { Chemical } \\
\text { method }\end{array}$ & ZnO MNSs & Not mentioned & $\begin{array}{l}\text { Nanoscopic filopodia-like } \\
\text { spike coating }\end{array}$ & $\begin{array}{l}\text { Interfere with viral attachment } \\
\text { and cell-to-cell spread }\end{array}$ \\
\hline $\begin{array}{l}\text { Farouk and Shebl } \\
2018^{[24]}\end{array}$ & $\begin{array}{l}\text { Chemical } \\
\text { method }\end{array}$ & $\begin{array}{l}\text { 1. H-ZNPs } \\
\text { 2. OA-ZNPs } \\
\text { 3. C-ZNPs }\end{array}$ & $\begin{array}{l}1.7 \\
2.5 \\
3.5 \\
\end{array}$ & $\begin{array}{l}\text { 1. Naked } \\
\text { 2. Oleic acid coating } \\
\text { 3. Naked }\end{array}$ & $\begin{array}{l}\text { Prevent viral adsorption to the } \\
\text { cells }\end{array}$ \\
\hline $\begin{array}{l}\text { Tavakoli et al. } \\
2018^{[25]}\end{array}$ & $\begin{array}{l}\text { Chemical } \\
\text { method }\end{array}$ & $\begin{array}{l}\text { 1. } \mathrm{ZnO}-\mathrm{NPs} \\
\text { 2. } \mathrm{ZnO}-\mathrm{PEG}-\mathrm{NPs}\end{array}$ & $20-50$ & $\begin{array}{l}\text { 1. Naked } \\
\text { 2. Polyethylene glycol } \\
\text { coating }\end{array}$ & Not mentioned \\
\hline $\begin{array}{l}\text { Tavakoli and } \\
\text { Hashemzadeh } \\
2019^{[26]}\end{array}$ & $\begin{array}{l}\text { Not } \\
\text { mentioned }\end{array}$ & CuO-NPs & 40 & Naked & $\begin{array}{l}\text { Oxidation of viral proteins and } \\
\text { degradation of viral genome }\end{array}$ \\
\hline $\begin{array}{l}\text { Trigilio et al. } \\
2012^{[4]}\end{array}$ & $\begin{array}{l}\text { Chemical } \\
\text { method }\end{array}$ & $\mathrm{SnO}_{2}$ nanowires & $50-100$ & Naked & $\begin{array}{l}\text { Interfere with viral attachment } \\
\text { and cell-to-cell spread }\end{array}$ \\
\hline $\begin{array}{l}\text { Barras et al. } \\
2016^{[30]}\end{array}$ & $\begin{array}{l}\text { Chemical } \\
\text { method }\end{array}$ & $\begin{array}{l}\text { 1. } \mathrm{B} / \mathrm{CDs} \\
\text { 2. } 3-\mathrm{AB} / \mathrm{CDs} \\
\text { 3. } 4-\mathrm{AB} / \mathrm{CDs}\end{array}$ & $\begin{array}{l}\text { 1. } 14 \pm 4 \\
\text { 2. } 24 \pm 6 \\
\text { 3. } 22 \pm 7\end{array}$ & Naked & $\begin{array}{l}\text { Do not inhibit viral entry } \\
\text { Interfere with virus-cell } \\
\text { interactions } \\
\text { Interfere with virus-cell } \\
\text { interactions }\end{array}$ \\
\hline $\begin{array}{l}\text { Klimova et al. } \\
2019^{[32]}\end{array}$ & $\begin{array}{l}\text { Chemical } \\
\text { method }\end{array}$ & Fullerene (dnC60) & $50-100$ & Naked & Not mentioned \\
\hline
\end{tabular}


Table 2. Continued

\begin{tabular}{|c|c|c|c|c|c|}
\hline First author & $\begin{array}{l}\text { Synthesis } \\
\text { mechanism }\end{array}$ & $\begin{array}{l}\text { Nanoparticle } \\
\text { type }\end{array}$ & $\begin{array}{l}\text { Nanoparticle size } \\
(\mathrm{nm})\end{array}$ & Nanoparticle coating & Antiviral mechanism \\
\hline $\begin{array}{l}\text { Sametband et al. } \\
2013^{[34]}\end{array}$ & $\begin{array}{l}\text { Chemical } \\
\text { method }\end{array}$ & $\begin{array}{l}\text { 1. } \mathrm{GO} \\
\text { 2. } \mathrm{rGO}-\mathrm{SO}_{3}\end{array}$ & Not mentioned & Naked & $\begin{array}{l}\text { Interfere with viral attachment } \\
\text { and cell-to-cell spread }\end{array}$ \\
\hline $\begin{array}{l}\text { Donskyi et al. } \\
2019^{[35]}\end{array}$ & $\begin{array}{l}\text { Physical } \\
\text { method }\end{array}$ & $\begin{array}{l}\text { Nanographene } \\
\text { sheet }\end{array}$ & $53.4-140.4$ & Naked & Not mentioned \\
\hline $\begin{array}{l}\text { Shen et al. } \\
2019^{[36]}\end{array}$ & $\begin{array}{l}\text { Physical } \\
\text { method }\end{array}$ & R. tanguticum NPs & $50-219$ & Naked & $\begin{array}{l}\text { Interfere with viral attachment } \\
\text { and replication stages }\end{array}$ \\
\hline $\begin{array}{l}\text { Tahara et al. } \\
2018^{[37]}\end{array}$ & $\begin{array}{l}\text { Not } \\
\text { mentioned }\end{array}$ & $\begin{array}{l}\text { 1. SA liposomes } \\
\text { 2. DCP liposomes } \\
\text { 3. Neutral } \\
\text { liposomes }\end{array}$ & $\sim 100$ & Naked & Block viral entry \\
\hline $\begin{array}{l}\text { Luganini et al. } \\
2011^{[39]}\end{array}$ & $\begin{array}{l}\text { Chemical } \\
\text { method }\end{array}$ & Dendrimers & Not mentioned & Naked & $\begin{array}{l}\text { Block viral attachment and } \\
\text { interfere with viral replication }\end{array}$ \\
\hline $\begin{array}{l}\text { Tarallo et al. } \\
2013^{[40]}\end{array}$ & $\begin{array}{l}\text { Chemical } \\
\text { method }\end{array}$ & Dendrimers & 12 & Naked & Block viral entry of \\
\hline
\end{tabular}

by L. coccineus (10.12-27.89 nm) and M. lutea (8.91-14.48 nm) extracts had antiviral activities against HSV-1 infection. They also suggested that the antiviral activity of AgNPs may be related to the blockage of the penetration process of the virus because of the interaction with viral envelope glycoproteins. Furthermore, they hypothesized that AgNPs can negatively affect the viral replication process.

In 2019, Aridass et al. ${ }^{[7]}$ synthesized biogenic AgNPs by seaweed Sargassum wightii to investigate their potent antiviral property against HSV-1 infection. The study revealed that Sw-Ag NPs have anti-HSV-1 activity with a dose-dependent manner. Moreover, the study indicated that $\mathrm{Sw}_{w} \mathrm{Ag} \mathrm{NPs}$ at $2.5 \mu \mathrm{l} / \mathrm{ml}$ reduce $70 \%$ HSV-1 cytopathogenic effect (CPE), while they showed $84.58 \%$ cell viability in this concentration.

In 2020, El-Sheekh et al. ${ }^{[20]}$ evaluated greenly biosynthesized AgNPs for their ability to inhibit HSV-1. In this study, the bluegreen algal strain Oscillatoria spp. was used to produce AgNPs. El-Sheekh et al. ${ }^{[20]}$ described that $\mathrm{Ag}_{2} \mathrm{O}$ O|AgO-Nps (14.42-48.97 $\mathrm{nm}$ ) produced by algae inhibit the replication of HSV-1 in a dose-dependent manner and reduce $90 \%$ of HSV- 1 CPE at 31.25 $\mu \mathrm{l} / \mathrm{ml}$.

\subsection{Gold-based Nanoparticles}

In 2010, Baram-Pinto et al. ${ }^{[3]}$ synthesized functionalized gold NPs capped by mercaptoethanesulfonate (Au-MES NPs) and investigated the Au-MES NPs potential as HSV-1 inhibitors. Their results showed that Au-MES NPs inhibited HSV-1 infection by blocking the attachment and cell-to-cell spread. The antiviral activity of Au-MES NPs is based on the principle that they imitate cellular HS. As a result, they compete with HSV-1 binding to the host cells. Additionally, the authors suggested that the soluble MES and unmodified gold NPs were unable to inhibit HSV-1 infection, which illustrated the significance of spatially oriented functional groups attached to an NP core in viral inhibition.

In 2018, Halder et al. ${ }^{[21]}$ evaluated the antiviral efficacy of monodispersed gold NPs (GAunps) that were synthesized in one-pot reduction reaction by using gallic acid. The results showed that GAunps $(7.86 \pm 3.3 \mathrm{~nm})$ reduced the formation of viral plaque in a dose-dependent manner. Furthermore, microscopic analysis showed that the GAunps-treated cells had intact morphology with minor cell damage compared with untreated cells. Halder et al. ${ }^{[21]}$ suggested that GAunp inhibited HSV-1 infection by blocking viral attachment and entry. In addition, they claimed that GAunps entered the cells because of their shape, size, and charge. As a result, GAunps might be invaded into infected Vero cells and inhibited viral reproduction.

In 2019, Aridass et al. ${ }^{[7]}$ examined the antiviral potential of AuNPs produced by seaweed Sargassum wightii against HSV1 infection. The anti-HSV-1 activity of AuNPs was determined by the CPE reduction method. The dose response inhibition assay indicated that Sw-AuNPs reduced HSV-1 CPE at $10 \mu \mathrm{l} /$ $\mathrm{ml}$, while cytotoxicity assay showed that $\mathrm{Sw}$-AgNPs were nontoxic at concentrations $>25 \mu \mathrm{l} / \mathrm{ml}$ and showed $85.1 \%$ cell viability.

In 2020, El-Sheek et al. ${ }^{[20]}$ performed another study and showed the effect of algae-biosynthesized AuNPs against HSV1 infection by investigating the difference between the virus titers in untreated and treated Vero cells. Their results revealed that AuNPs (15.60-77.13 nm) produced by Spirulina platensis inhibited HSV-1 replication in a dose-dependent manner resulting in 90\% reduction in CPE at $31.25 \mu \mathrm{l} / \mathrm{ml}$. 
In 2020, I et al. ${ }^{[22]}$ assayed the anti-HSV-1 potential of three types of gold NPs including NPAuG1-S2, NPAuG2-S4, and NPAuG3-S8 on human neuroepithelioma cell line SK-NMC and Vero cells. Their data showed that both NPAuG2-S4 and NPAuG3-S8 inhibited the HSV-1 infectivity, while no inhibitory effect was observed for NPAuG1-S2. The results elucidated that both NPAuG2-S4 and NPAuG3-S8 could significantly inhibit the infection because of the protection of SK-N-MC cells against viral infection ( $>70 \%$ and $>75 \%$, respectively), which means that these AuNPs inhibited viral entry by attaching to SK-N-MC receptors or viral peripheral glycoproteins. Moreover, another experiment on Vero cells evaluated the activity of AuNPs toward HSV-1 independent of the used cell. The data illustrated that NPAuG2-S4 and NPAuG3-S8 inhibited the HSV-1 infectivity by $20 \%$ and $50 \%$, respectively. I et al. ${ }^{[22]}$ suggested that NPAuG3-S8 could be an appropriate candidate for further study because of their dual behaviors, which include acting against HSV-1 and protecting target cells against HSV-1 infection. Besides, I et al. ${ }^{[22]}$ performed histological studies at 10,24 , and 48 h postinoculation of NPAuG3-S8 in mouse brains. In this study, no hemorrhage, edema, or presence of areas of necrosis was not detected in treated mice. Furthermore, no damage or alteration onto the brain epithelium was detected, except for a minimal to moderate proliferation of choroid plexuses epithelium detected in two mice. Their results suggested that NPAuG3-S8 could be a possible treatment against HSV-1 infection.

\subsection{Zinc-based NPs}

In 2011, Mishra et al. ${ }^{[23]}$ showed the high virostatic potential of micro-nano filopodia-like $\mathrm{ZnO}$ structures against HSV-1 infection. In this study, ZnO micro-nano structures (MNSs) capped by nanoscopic filopodia-like spikes were used as antiviral agents. The main results demonstrated that ZnO MNSs affected virus-cell interactions and interfered with viral attachment at the entry stage and cell-to-cell spread. Mishra et al. ${ }^{[23]}$ suggested that ZnO MNSs capped by nanoscopic filopodia-like spikes imitated HS-rich filopodia structures on the cell surface. Consequently, negatively charged $\mathrm{ZnO}$ nanospikes competed for viral binding to cellular HS. Mishra et al. ${ }^{[23]}$ utilized embryos from zebrafish, which provided a quick and easy model for testing HSV-1 infection in vivo. According to their observation, ZnO MNSs prophylactically blocked infection in zebrafish embryos. Therefore, the authors suggested that ZnO MNSs can be considered a promising anti-HSV prophylactic agent.

In 2018, Farouk and Shebl used three surface-modified zinc oxide NPs (ZNPs) for the inhibition of HSV-1. In this study, they utilized hydroxyl group-rich ZNPs (H-ZNPs), oleic acidmodified ZNPs (OA-ZNPs), and chitosan-zinc NPs (C-ZNPs) synthesized by the chemical method. Data revealed that
$\mathrm{H}$-ZNPs and OA-ZNPs reduced the viral titer in the cell pretreatment assay $(12.9 \%$ and $7.7 \%$, respectively), while C-ZNPs did not show viral inhibition. By contrast, both C-ZNPs and H-ZNPs completely neutralized the virus after 24 h, whereas OA-ZNPs with 15\% inhibition after $24 \mathrm{~h}$ showed the least anti-HSV-1 property. In the cell pretreatment assay, Farouk and Shebl revealed the lower inhibitory activity of $\mathrm{H}$-ZNPs than their high antiviral activity when the HSV-1 was directly incubated with NPs, which supported the assumption that H-ZNPs neutralized the HSV-1. Furthermore, they suggested that OA-ZNPs interfered with the hydrophobic interaction because of their hydrophobic coat and that C-ZNPs entrapped the viral particles and prevented viral adsorption to the cells ${ }^{[24]}$.

In 2018, Tavakoli et al. ${ }^{[25]}$ conducted another study to evaluate the efficiency of polyethylene glycol-coated zinc oxide NPs (ZnO-PEG-NPs) and zinc oxide NPs (ZnO-NPs) against HSV1 infection. The results illustrated that both ZnO-PEG-NPs and $\mathrm{ZnO}-\mathrm{NPs}$ demonstrated antiviral activity only in the cell post-treatment assay. Furthermore, ZnO-PEG-NPs showed a higher antiviral inhibitory than unPEGlyated $\mathrm{ZnO}$-NPs at the same concentration, which suggested that the PEG coat had a considerable role in increasing the antiviral potency of NPs. In addition, PEG coating decreased the cell cytotoxicity of NPs and simultaneously increased their antiviral activity.

\subsection{Copper-based NPs}

In 2019, Tavakoli and Hashemzadeh investigated the inhibitory capacity of copper oxide NPs (CuO-Nps) against HSV-1 infection. The results indicated that CuO-NPs (40 nm) inhibited the HSV-1 infectivity in a dose-dependent manner. They suggested several mechanisms to explain the CuO-NPs anti-HSV-1 property, including oxidation of viral proteins and degradation of the viral genome, which were caused by the release of copper ions from the CuO-NPs and subsequent production of reactive oxygen species ${ }^{[26]}$.

\subsection{Tin-based NPs}

In 2012, Trigilio et al. ${ }^{[4]}$ explained the antiviral ability of tin oxide $\left(\mathrm{SnO}_{2}\right)$ nanowires. Their experiment results demonstrated that $\mathrm{SnO}_{2}$ nanowires reduced the plaque size by $77 \%$, viral entry by 75\%, and cell-to-cell spread by $99 \%$. Trigilio et al. ${ }^{[4]}$ elucidated that negatively charged $\mathrm{SnO}_{2}$ nanowires competed with cellular HS for HSV-1 binding by mimicking its natural target (HS) and thus efficiently inhibited viral entry as well as cell-to-cell spread.

\section{Carbon-based Anti-HSV-1 NPs}

Carbon-based NPs are carbon derivate and have various applications in biomedicine. Carbon-based NPs include carbon dot (CD), fullerenes, graphene, carbon nanofibers, carbon nanotubes, and carbon black. The antiviral potential 
of several carbon-based NPs against HSV-1 infection is discussed below.

\subsection{Carbon Dots}

Carbon dots, also known as carbon quantum dots, are a novel class of nanomaterials having at least one dimension smaller than $10 \mathrm{~nm}$. Recently, CDs have attracted great attention owing to their desirable physicochemical properties including nontoxicity, broad-spectrum antimicrobial activity, low cost, and ease of synthesis. Despite the small number of studies on $C D$ antiviral potential, they are good candidates for further studies because of their remarkable properties and functional groups, which activate them against a virus ${ }^{[27-29]}$.

In 2016, Barras et al. ${ }^{[30]}$ investigated the antiviral potency of functional CDs as HSV-1 entry inhibitors. Phenyl-boronic acid (PBA), 3-aminophenylboronic acid (3-APBA), and 4-APBA were used as $C D$ precursors to produce $B / C D s, 3-A B / C D$, and $4-A B / C D$ s. Both antiviral and cytotoxicity assays were applied on Vero cells and human lung cancer cells (A549). The cytotoxicity assay results demonstrated that none of the three CDs are cytotoxic on A549 cells at concentrations up to $300 \mu \mathrm{g} / \mathrm{ml}$. Furthermore, $B / C D$ s and $4-A B / C D$ s showed no significant cytotoxicity against Vero cells, while $3-A B / C D$ s showed moderate cytotoxicity. The results of the antiviral assay indicated that $B / C D$ s did not inhibit viral entry. By contrast, $3-A B / C D$ s and $4-A B / C D$ s inhibited the virus entry in a dose-dependent manner. They explained that the zeta potential of three CDs is negative $(B / C D s-19 \pm 5 \mathrm{mV}, 3-A B /$ CDs $-23 \pm 7 \mathrm{mV}$, and $4-\mathrm{AB} / \mathrm{CDs}-25 \pm 5$ ); however, $3-\mathrm{AB} / \mathrm{CDs}$ and $4-A B / C D$ s interacted with Vero cells stronger than viral particles. Consequently, they inhibited HSV-1 infection by interfering with virus-cell interactions. Barras et al. ${ }^{[30]}$ hypothesized that the NH2 groups in $3-A B / C D$ s and $4-A B /$ CDs might bind to heparan or 3-OS heparan receptors and subsequently interfere with cell-virus interactions at the early stage of virus entry.

\subsection{Fullerenes}

Fullerenes are large carbon cage molecules that are considered three-dimensional analogs of benzene. Fullerenes have various forms including $\mathrm{C}_{60^{\prime}} \mathrm{C}_{70^{\prime}} \mathrm{C}_{78^{\prime}} \mathrm{C}_{84^{\prime}}$ and $\mathrm{C}_{86^{\circ}} \mathrm{C}_{60^{\prime}}$ also known as buckminsterfullerene or Bucky ball, is form of fullerene with spherical and symmetrical structure. $\mathrm{C}_{60}$ is a suitable therapeutic agent candidate owing to its remarkable properties, including antioxidant, anti-inflammatory, and nontoxicity ${ }^{[31]}$.

In 2019, Klimova et al. ${ }^{[32]}$ elucidated that aqueous fullerene $\mathrm{C}_{60}$ dispersion $\left(\mathrm{dnC}_{60}\right)$ is a suppressor of HSV-1. In their study, dnC60 demonstrated considerable viral inhibitory activity with low cytotoxicity. The result of the plaque reduction assay showed that dnC60 inhibited HSV-1 infection in the pretreatment and post-treatment assays $(87 \pm 2.6 \%$ and $60 \pm 4.4 \%$, respectively). Furthermore, $\mathrm{dnC}_{60}$ significantly inhibited infection in the virucidal assay by $98.2 \pm 1 \%$. Moreover, Klimova et al. ${ }^{[32]}$ tested $\mathrm{C}_{60}$ solution in a mouse model of cutaneous HSV- 1 infection. In $\mathrm{dnC}_{60}$-treated mice, as in ACV-treated mice, the clinical manifestations of HSV-1 infection on skin were minimal, and a statistical decrease of lesion formation was observed two days after infection. Full recovery was achieved on days eight and nine post-infection. They highlighted that $\mathrm{dnC}_{60}$ had anti-HSV-1 activity $24 \mathrm{~h}$ earlier compared with ACV and inhibit the virus at a concentration lower than 500-fold.

\subsection{Graphene}

Graphene is a two-dimensional sheet of carbon, which has monolayer (single layer), bilayer (two layers), and tri-layer (three layers) structures. Each of these structures represents different properties depending on the number of layers. Graphene oxide (G0) is a monolayer material with high oxygen content. Graphene and G0 exhibit antiviral activity owing to their unique physical and chemical properties. Several possible mechanisms are presented about the antiviral effect of graphene and $\mathrm{GO}$, including physical interaction with the virus, antiviral activity through photo-catalysis, hydrophobic interactions, electrostatic interactions, and mimicking of the cell surface ${ }^{[28,33]}$.

In 2013, Sametband et al. ${ }^{[34]}$ evaluated the antiviral potential of functionalized $\mathrm{GO}$, and they tested $\mathrm{GO}$ and partially reduced sulfonated $\mathrm{GO}\left(\mathrm{rGO}_{-} \mathrm{SO}_{3}\right)$ against $\mathrm{HSV}-1$ infection. Both nanomaterials are negatively charged because of carboxyl and sulfonate which are negatively charged groups, and both have approximately the same potential. The results of the plaque assay indicated that $\mathrm{GO}$ and $\mathrm{rGO}-\mathrm{SO}_{3}$ prevented infection at $\mathrm{ng} / \mathrm{ml}$ concentrations. The authors suggested that both $\mathrm{GO}$ and $\mathrm{rGO}-\mathrm{SO}_{3}$ could inhibit viral attachment because of their functionalized sulfonated groups $\left(\mathrm{rGO}_{-} \mathrm{SO}_{3}\right)$, which resulted in the imitation of the cell surface receptor HS and competed with HSV-1 for binding to HS. By contrast, none of the mentioned nanomaterials showed inhibitory effects on the cell-to-cell spread.

In 2019, Donskyi et al. ${ }^{[35]}$ examined the interaction between nanographene sheet and HSV-1. They synthesized different graphene derivatives by the conjugation of different chainlength fatty amines and polyglycerol sulfate to evaluate their antiviral potential on HSV-1. In their study, graphene sheets bound to the virus through electrostatic interactions of polyglycerol sulfates and alkyl chains caused antiviral activity through secondary hydrophobic interactions. In their study, longer alkyl chains showed a higher antiviral effect on HSV-1 with high cytotoxicity on infected cells, exhibiting a 
strong correlation between the length of fatty amines and their toxicity. Donskyi et al. ${ }^{[35]}$ claimed that $\mathrm{C}_{6}$ and $\mathrm{C}_{9}$ had the best anti-HSV-1 activity in terms of cytotoxicity and antiviral activity. Moreover, they prove that hydrophobic and electrostatic interaction caused viral inhibitory activity synergistically.

\section{Organic Anti-HSV-1 NPs}

Organic NPs are polymeric NPs such as dendrimers, liposomes, ferritin, and micelles, which are appropriate candidates as therapeutic agents with lower toxicity and more appropriate drug delivery options ${ }^{[11]}$.

\subsection{R. tanguticum NPs}

Rheum tanguticum is one of the most significant and famous traditional Chinese medicine that has become endangered. Rhubarb is the rhizomes of $R$. tanguticum containing several chemical compounds. Rhubarb possesses a broad range of pharmaceutical applications, including antimicrobial, antioxidant, antitumor, and anti-inflammatory properties. In 2019, Shen et al. ${ }^{[36]}$ synthesized $R$. tanguticum NPs to enhance its antiviral potency against HSV-1 infection. In their study, R. tanguticum NPs exhibited anti-HSV-1 activity through inactivation of cell-free virions and showed interference with viral attachment, entry, and replication stages in the adsorption and penetration assays. The result of the plaque reduction assay demonstrated that $R$. tanguticum NPs reduced viral plaque by $50 \%$. In addition, the quantification of the mRNA expression of HSV-1 immediate-early gene (ICP4) and early gene (ICP8) showed the downregulation of ICP4 and ICP8 expression levels, confirming the interference of $R$. tanguticum NPs with the whole stage of viral replication. Besides, Shen et al. ${ }^{[36]}$ investigated the efficacy of $R$. tanguticum NPs in vivo using a mice HSV-1 encephalitis model. The $R$. tanguticumtreated mice showed a higher survival rate, lower viral titer, and alleviated clinical signs than the untreated control mice with the efficacy similar to that of ACV. Their results also indicated that $R$. tanguticum NPs could suppress the expression levels of virus proteins in vivo.

\subsection{Liposomes}

In 2018, Tahara et al. ${ }^{[37]}$ proved that cationic liposomes with stearylamin (SA) made strong inhibitory effects on viral infectivity without loading antiviral drugs. They produced liposomes with different surface charges and particle sizes to compare their viral inhibitory potential. In this study, the authors prepared uncharged, negatively charged, and positively charged liposomes. Stearylamin and dicetyl phosphate (DCP) were utilized to produce positively and negatively charged liposomes, respectively. The result of the plaque reduction assay demonstrated that cationic SA liposomes with positive zeta potential had a significant anti-HSV-1 effect, resulting in smaller plaques. By contrast, neutral and DCP liposomes indicated weaker anti-HSV-1 activity. Tahara et al. ${ }^{[37]}$ suggested that SA liposomes interfere with virus-cell interaction and block virus entry by binding to the cell membrane.

\subsection{Dendrimers}

Dendrimers are polymeric nanostructures with a diameter of $<100 \mathrm{~nm}$. Dendrimers can be utilized as vehicles for the delivery of antiviral therapeutics, siRNA, and DNA. Additionally, dendrimers have demonstrated antiviral properties ${ }^{[38]}$. In 2011, Luganini et al. ${ }^{[39]}$ proved that SB105 and SB105_A10 inhibited HSV-1 infection in a dose-dependent manner. SB105 and its derivative SB105_A10 are peptide-derived dendrimers obtained from the M6 prototype, a tetra-branched dendrimer based on a lysine core. The results revealed that both SB105 and SB105 A10 decreased HSV-1 replication by over $90 \%$. Luganini et al. ${ }^{[39]}$ hypothesized that the ionic interactions between the negatively charged carboxyl/sulfate groups of the HS and polycationic structure of SB105 and SB105_A10 block the viral attachment to cellular HS. Moreover, the combination of ACV and SB105_A10 displayed notable synergistic activity because of the combined interference of two different replication phases of the life cycle of HSV.

In 2013, Tarallo et al. ${ }^{[40]}$ studied the antiviral potential of dendrimers. They evaluated the anti-HSV-1 activity of a dendrimer whose termini functionalized with the HSV1 derived peptide gH625. This peptide was indicated to have efficient antiviral inhibitory effects. In this study, peptidodendrimers inhibited the virus more than $80 \%$ at the concentration of $280 \mathrm{nM} / \mathrm{ml}$, while intact dendrimers had $35 \%$ viral inhibition at the same concentration. This result confirmed that the dendrimer structure possessed antiviral activity, which could be increased by the addition of a particular amino acid sequence to its terminal sites. Peptidodendrimers inhibited HSV-1 infection at the early stage of the viral entry by interacting with viral glycoproteins. Taken together, modifying dendrimers with antiviral peptides could be an efficacious approach for the development of a novel class of antiviral agents.

\section{Acyclovir Nanocarriers}

Nanocarriers are colloidal NPs with diameter of 1-100 nm. Some nanocarriers were found to have considerable potential for transportation of different substances particularly therapeutic agents. Nanocarriers have unique properties including high solubility and stability, low toxicity, sustained and targeted delivery, and appropriate pharmacokinetics. This section will explain the capability of several nanocarriers for ACV delivery ${ }^{[41]}$. 


\subsection{Solid Lipid NPs}

Solid lipid NPs (SLNs) are considered highly appropriate options for ACV delivery. Acyclovir loading in solid lipid NPs improves the oral bioavailability of ACV because of several reasons. First, NPs increase the absorption of ACV in the gastrointestinal tract owing to their large surface area and activation of gastrointestinal lipases by their triglycerides. Second, SLNs stimulate lymphatic lipid flux by increasing lipoprotein formation, contributing to higher bioavailability and lymphatic delivery. Furthermore, M-cells in Peyer's patch take NPs more preferentially, resulting in the improvement of drug absorption.

In 2019, Kondel et al. ${ }^{[42]}$ evaluated ACV-loaded SLNs, which had an average size of $131 \pm 41.44 \mathrm{~nm}$ and $-16 \pm 1.90 \mathrm{mV}$ zeta potential. The cytotoxicity assay results demonstrated that both ACV and ACV SLNs had cytotoxicity at the concentration of $\geq 100 \mu \mathrm{g} / \mathrm{ml}$. However, the results of the plaque reduction assay exhibited that ACV SLNs had notable antiviral effects at lower concentrations, and multiple doses of conventional ACV were equivalent to a single dose of ACV-loaded solid lipid NPs.

In 2020, Hassan et al. ${ }^{[8]}$ assessed SLNs as ACV carriers and tested the pharmacokinetic parameters and oral bioavailability of SLNs (134 nm). Solid lipids, which were utilized for producing SLNs, were safe, and their adverse toxicity is low. The result demonstrated that ACV-loaded SLNs had significant oral bioavailability compared with commercial ACV suspensions, and lower dosage of ACV-loaded SLNs provided similar therapeutic effects as commercial oral suspensions. Thus, ACV-loaded SLNs reduce the side effects of taking frequent and high doses of ACV, especially acute kidney injury. They concluded that SLNs exhibited potential as an oral delivery vehicle for ACV.

\subsection{Liposomes and Niosomes}

Liposomes are bilayer vesicles with spherical structures made from nontoxic phospholipids and cholesterol. Liposomes are considered promising candidates for nano-particulate drug delivery systems because of their properties (such as small size) and their physical and chemical characteristics. Niosomes are similar to liposomes in terms of pharmaceutical properties. However, niosomes consist of nonionic surfactant. Furthermore, niosomes are preferable drug carriers because of their advantages, including great stability, low toxicity, high availability and biocompatibility, lower costs, and lack of variable purity problems associated with phospholipids ${ }^{[43,44]}$.

In 2007, Mukherjee et al. ${ }^{[45]}$ compared the sustained release of ACV from nano-niosomes based on Span 20 and nano-liposomes based on cholesterol and soya L- $\alpha$ lecithin. The results showed that the rate of drug loading in niosomes was higher than that in liposomes. The results also indicated that liposomes released
$90 \%$ of the drug within 150 min, while niosomes released just $50 \%$ of the drug within $200 \mathrm{~min}$. Therefore, Mukherjee et al. ${ }^{[45]}$ suggested that the slower release rate of drug molecules from the niosome and considerable amount of ACV might be related to the interaction between Span 20 of niosomes and the amino groups in ACV.

In 2014, Mirzaei et al. ${ }^{[46]}$ also evaluated the efficacy of ACVloaded nano-niosomes (ACV-N) against HSV-1 infection. They prepared and characterized five nano-niosomes with different formulations to compare their drug delivery potential. Moreover, the cytotoxicity of ACV- loaded niosomes and their anti-HSV-1 activity were assessed on HeLa cell lines. The authors claimed that niosomes with optimized formulation, which consisted of Span 60, cholesterol, and D- $\alpha$-tocopheryl polyethylene glycol succinate, were appropriate ACV carriers. The results revealed that ACV-N $(122.6 \pm 0.2 \mathrm{~nm})$ released $11.7 \%$ of the drug in $1 \mathrm{~h}$, and ACV-loaded nisomes released a lower amount of drug when compared with the free drug solution. These data confirmed that niosomes could optimize the release of ACV. The results of the cytotoxicity assay illustrated that ACV-N is not toxic to HeLa cells. Additionally, the antiviral effects of ACV-N were three times greater than the free drug solution in TCID50 experiment. Mirzaei et al. ${ }^{[46]}$ highlighted the higher antiviral activity of ACV-N through simpler endocytosis and fusion processes.

In 2017, Salem et al. ${ }^{[47]}$ claimed that ACV-gold NP-loaded liposomes could be a promising candidate for treating viral infections. They used nano-liposomes as carriers of ACV conjugated with gold NPs. Gold NPs were utilized as reducing agent and capping agent, and the size of NPs after conjugation with ACV increased from 16 to $20 \mathrm{~nm}$. ACV-gold NPs were encapsulated in liposomes successfully. The results showed the good drug release of ACV-gold NPs. Salem et al. ${ }^{[4]]}$ asserted that the electrostatic repulsion between negatively charged liposomes and strong negatively charged ACV-gold NPs increase the amount of drug released.

\subsection{Bilosomes}

Bilosomes are novel nanocarriers similar to niosomes with extra bile salts incorporated with the bilayer lipids. Conventional nanocarriers such as liposomes and niosomes release encapsulated drug molecules before reaching the target location. The intestinal bile salt deforms and lyses the vesicle membrane. Bilosomes overcome this limitation by protecting the drug from enzymatic digestion. Additionally, bilosomes possess great stability and absorption and increase the oral bioavailability of drugs.

In 2020, Rizwanullah et al. ${ }^{[48]}$ suggested bilosomes as good candidates and safe carriers that significantly enhance the absorption and bioavailability of ACV. They compared 
optimized ACV-loaded bilosomes with ACV suspension and its commercial formulation. Optimized ACV-loaded bilosomes contained $10 \mathrm{mg}$ of cholesterol, $50 \mathrm{mg}$ of surfactant (Span 60 , Tween 80 ), and $7.5 \mathrm{mg}$ of bile salt (sodium glycocholate). The results revealed that ACV-loaded bilosomes released nearly $95 \%$ of drug after $24 \mathrm{~h}$, while ACV suspension and commercial ACV released $40.23 \pm 5.32 \%$ and $52.74 \pm 5.84 \%$ of the drug after $24 \mathrm{~h}$, respectively. Acyclovir-loaded bilosomes indicated notably higher drug release than the others. Besides, ACV-loaded bilosomes exhibited considerable increment in penetration and bioavailability.

\subsection{Chitosan Nanospheres}

Chitosan is a natural linear polycationic polysaccharide that has biomedical applications because of its properties, including low toxicity and biodegradability, high biocompatibility, low cost, unique structure, and physicochemical characteristics.

In 2018, Donalisio et al. ${ }^{[49]}$ evaluated ACV-loaded chitosan nanosphere nano-emulsion templating for the treatment of HSV infection. Acyclovir-loaded chitosan nanospheres had a size of $200 \mathrm{~nm}$ and a spherical shape. In their study, ACV-loaded chitosan nanospheres indicated substantial antiHSV-1 activity compared with free ACV, while unloaded NS did not display antiviral activity and cytotoxicity. Moreover, chitosan nanospheres showed higher skin permeation and prolonged ACV release than commercial formulation and free ACV.

\section{Conclusion}

NPs have enormous applications in pharmacy, biology, and medicine, particularly as drug delivery systems and antimicrobial agents. Different categories of NPs include inorganic NPs (metal and metal oxide NPs), organic NPs, and carbon-based NPs, which have demonstrated effective antiviral activity against HSV-1 infection. Several approaches are used to synthesize NPs, such as physical, chemical, and biological methods. In recent years, the advantages of biological NPs, such as being clean, green, cost effective, and less chemical toxicity, have attracted increased attention. The antiviral activity of NPs depends on several parameters including size, zeta potential, capping agent, surface modification, and NP type. In addition, the antiviral activity of NPs targets different stages of the HSV-1 life cycle including viral attachment, penetration, replication, and cellto-cell spread (Figure 1). Physical (shape, size, and charge) and chemical alterations (e.g., addition of tannic acid) of selected NPs certainly contribute to variations in mechanism and the level of their antiviral activity. For example, smaller NPs can enter the viral genome; thus, they are more probable to block/suppress genome-dependent processes such as replication rather than larger ones. Another critical factor that influences the antiviral activity of NPs is their surface charge. Positively charged NPs can enhance their uptake by host cells. Positively charged NPs have higher internalization than neutral and negatively charged NPs. In addition, external and experimental factors may result in different conclusions for the same NPs. Therefore, results of similar studies on NPs from a single family can be inconsistent ${ }^{[50]}$. Studies have shown that NPs mostly inhibit HSV-1 by interfering with its attachment to host cells and blocking viral entry. Among NPs, metal-based NPs, particularly silver and gold NPs, have exhibited considerable inhibitory effects on HSV1 infectivity. Moreover, NPs are considered suitable vehicles for the ACV delivery. Nanoparticles significantly enhance the bioavailability and permeation of ACV and have sustainable drug release. Consequently, patients require a lower dose of $A C V$, reducing the side effects of taking frequent and high doses of ACV. Taken together, NPs are eligible candidates for treating viral infection; however, utilizing NPs have toxicity and ecological effects with long-term exposure. 


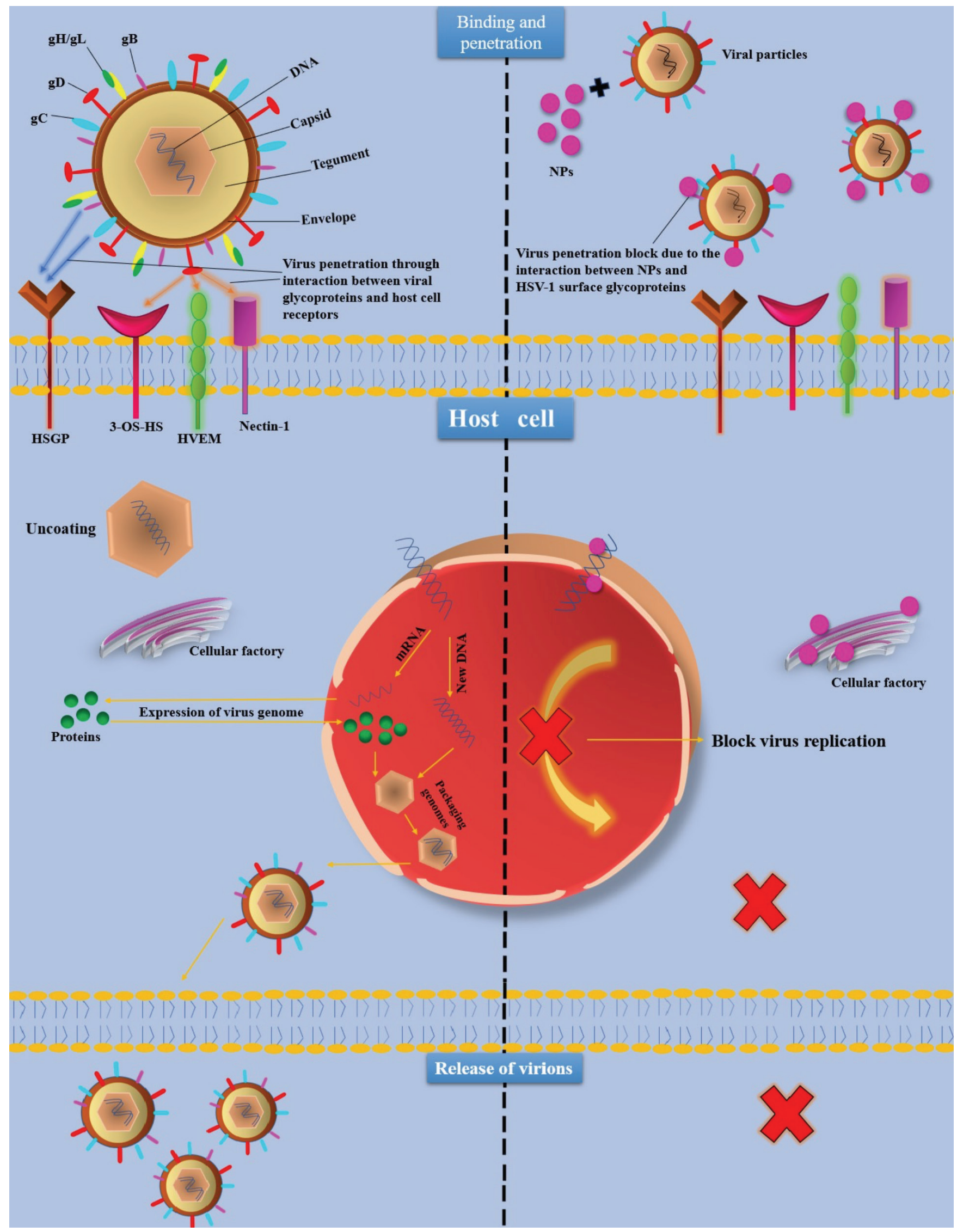

Figure 1. Anti-Herpes simplex virus type-1 mechanism of nanoparticles 


\section{Ethics}

Peer-review: Externally peer-reviewed.

\section{Authorship Contributions}

Concept: M.S., Design: M.A., Literature Search: M.A., Writing: M.A., N.B., Z.R., F.B., M.S.

Conflict of Interest: No conflict of interest was declared by the authors.

Financial Disclosure: The authors declared that this study received no financial support.

\section{References}

1. Duarte LF, Farias MA, Álvarez DM, Bueno SM, Riedel CA, González PA. Herpes Simplex Virus Type 1 Infection of the Central Nervous System: Insights Into Proposed Interrelationships With Neurodegenerative Disorders. Front Cell Neurosci. 2019;13:46.

2. Reske A, Pollara G, Krummenacher C, Chain BM, Katz DR. Understanding HSV-1 entry glycoproteins. Rev Med Virol. 2007;17:205-15.

3. Baram-Pinto D, Shukla S, Gedanken A, Sarid R. Inhibition of HSV-1 attachment, entry, and cell-to-cell spread by functionalized multivalent gold nanoparticles. Small. 2010;6:1044-50.

4. Trigilio J, Antoine TE, Paulowicz I, Mishra YK, Adelung R, Shukla D. Tin Oxide Nanowires Suppress Herpes Simplex Virus-1 Entry and Cell-to-Cell Membrane Fusion. PLoS One. 2012;7:1-9.

5. Ohtsu Y, Susaki Y, Noguchi K. Absorption, Distribution, Metabolism, and Excretion of the Novel Helicase-Primase Inhibitor, Amenamevir (ASP2151), in Rodents. Eur J Drug Metab Pharmacokinet. 2018;43:693-706.

6. Pires de Mello CP, Bloom DC, Paixão IC. Herpes simplex virus type-1: replication, latency, reactivation and its antiviral targets. Antivir Ther. 2016;21:277-86.

7. Aridass D, Seetharaman S, Govindaraju K, Parija P, Sasikala S, Ramesh Kumar MR. Anti-herpes simplex virus (HSV-1 and HSV-2) activity of biogenic gold and silver nanoparticles using seaweed Sargassum wightii. Indian J GeoMarine Sci. 2019:48:1252-7.

8. Hassan H, Bello RO, Adam SK, Alias E, Meor Mohd Affandi MMR, Shamsuddin AF, Basir R. Acyclovir-Loaded Solid Lipid Nanoparticles: Optimization, Characterization and Evaluation of Its Pharmacokinetic Profile. Nanomaterials (Basel). 2020;10:1785.

9. Rai $M$, Shegokar R. Metal nanoparticles in pharma. $1^{\text {st }}$ ed. Chapter: 15. Springer International Publisher. 2017:337-63.

10. Rai M, Deshmukh SD, Ingle AP, Gupta IR, Galdiero M, Galdiero S. Metal nanoparticles: The protective nanoshield against virus infection. Crit Rev Microbiol. 2016;42:46-56.

11. Jeyaraj M, Gurunathan $S$, Qasim M, Kang MH, Kim JH. A Comprehensive Review on the Synthesis, Characterization, and Biomedical Application of Platinum Nanoparticles. Nanomaterials (Basel). 2019;9:1719.

12. Dhand C, Dwivedi N, Loh XJ, Ying ANJ, Verma NK, Beuerman RW, Lakshminarayanan R, Ramakrishna S. Methods and Strategies for the Synthesis of Diverse Nanoparticles and their Applications: A Comprehensive Overview RSC Adv. 2015:5:105003-37.

13. Maduray K, Parboosing R. Metal Nanoparticles: a Promising Treatment for Viral and Arboviral Infections. Biol Trace Elem Res. 2021;199:3159-76.

14. Mohammed Fayaz A, Ao Z, Girilal M, Chen L, Xiao X, Kalaichelvan P, Yao $X$. Inactivation of microbial infectiousness by silver nanoparticles-coated condom: a new approach to inhibit HIV- and HSV-transmitted infection. Int J Nanomedicine. 2012;7:5007-18.
15. Gaikwad S, Ingle A, Gade A, Rai M, Falanga A, Incoronato N, Russo L, Galdiero $\mathrm{S}$, Galdiero M. Antiviral activity of mycosynthesized silver nanoparticles against herpes simplex virus and human parainfluenza virus type 3 . Int J Nanomedicine. 2013;8:4303-14.

16. Kwon HJ, Jeong JH, Lee SW, Ryu YB, Jeong HJ, Jung K, Lim JS, Cho KO, Lee WS, Rho MC, Park SJ. In vitro anti-reovirus activity of kuraridin isolated from Sophora flavescens against viral replication and hemagglutination. J Pharmacol Sci. 2015:128:159-69.

17. Ramadan MA, Shawkey $A E$, Rabeh MA, Abdellatif AO. Promising antimicrobial activities of oil and silver nanoparticles obtained from Melaleuca alternifolia leaves against selected skin-infecting pathogens. J Herb Med. 2020;20:100289.

18. Szymańska E, Orłowski P, Winnicka K, Tomaszewska E, Bąska P, Celichowski G, Grobelny J, Basa A, Krzyżowska M. Multifunctional Tannic Acid/Silver Nanoparticle-Based Mucoadhesive Hydrogel for Improved Local Treatment of HSV Infection: In Vitro and In Vivo Studies. Int J Mol Sci. 2018;19:387.

19. Haggag EG, Elshamy AM, Rabeh MA, Gabr NM, Salem M, Youssif KA, Samir A, Bin Muhsinah A, Alsayari A, Abdelmohsen UR. Antiviral potential of green synthesized silver nanoparticles of Lampranthus coccineus and Malephora lutea. Int J Nanomedicine. 2019;14:6217-29.

20. El-Sheekh MM, Shabaan MT, Hassan L, Morsi HH. Antiviral activity of algae biosynthesized silver and gold nanoparticles against Herps Simplex (HSV-1) virus in vitro using cell-line culture technique. Int J Environ Health Res. 2020:1-12.

21. Halder A, Das S, Ojha D, Chattopadhyay D, Mukherjee A. Highly monodispersed gold nanoparticles synthesis and inhibition of herpes simplex virus infections. Mater Sci Eng C Mater Biol Appl. 2018;89:413-21.

22. I RI, Mj S, R G, Fj M, Mj B, Ma MF. Gold Nanoparticles Crossing Blood-Brain Barrier Prevent HSV-1 Infection and Reduce Herpes Associated AmyloidBsecretion. J Clin Med. 2020;9:155.

23. Mishra YK, Adelung R, Röhl C, Shukla D, Spors F, Tiwari V. Virostatic potential of micro-nano filopodia-like $\mathrm{ZnO}$ structures against herpes simplex virus-1. Antiviral Res. 2011;92:305-12.

24. Farouk F, Shebl RI. Comparing Surface Chemical Modifications of Zinc Oxide Nanoparticles for Modulating their Antiviral Activity against Herpes Simplex Virus Type-1. Int J Nanoparticles Nanotech. 2018;4:1-14.

25. Tavakoli A, Ataei-Pirkooh A, Mm Sadeghi G, Bokharaei-Salim F, Sahrapour P, Kiani SJ, Moghoofei M, Farahmand M, Javanmard D, Monavari SH. Polyethylene glycol-coated zinc oxide nanoparticle: an efficient nanoweapon to fight against herpes simplex virus type 1. Nanomedicine (Lond). 2018;13:2675-90.

26. Tavakoli A, Hashemzadeh MS. Inhibition of herpes simplex virus type 1 by copper oxide nanoparticles. J Virol Methods. 2020;275:113688.

27. Liu ML, Bin Chen B, Li CM, Huang CZ. Carbon dots: Synthesis, formation mechanism, fluorescence origin and sensing applications. Green Chem. 2019;21:449-71.

28. Innocenzi P, Stagi L. Carbon-based antiviral nanomaterials: graphene, C-dots, and fullerenes. A perspective. Chem Sci. 2020;11:6606-22.

29. Bhartiya P, Singh A, Kumar H, Jain T, Singh BK, Dutta PK. Carbon dots: Chemistry, properties and applications. J Indian Chem. 2016;93:759-66.

30. Barras A, Pagneux Q, Sane F, Wang Q, Boukherroub R, Hober D, Szunerits S. High Efficiency of Functional Carbon Nanodots as Entry Inhibitors of Herpes Simplex Virus Type 1. ACS Appl Mater Interfaces. 2016;8:9004-13.

31. Thakral S, Mehta R. Fullerenes: An introduction and overview of their biological properties. Indian J Pharm Sci. 2006;68:13-9.

32. Klimova R, Andreev S, Momotyuk E, Demidova N, Fedorova N, Chernoryzh $Y$ Yurlov K, Turetskiy E, Baraboshkina E, Shershakova N, Simonov R, Kushch A Khaitov M, Gintsburg A. Aqueous fullerene C60 solution suppresses herpes simplex virus and cytomegalovirus infections. Fullerenes Nanotub. Carbon Nanostructures. 2019;28:487-99. 
33. Voynikov T, Nikolva I, Suzuki A, Higashino H, Petkova M, Mega N. A review on the properties and applications of perfluorocarbon emulsions. Acta medica Kinki University. 1990;15:1-20.

34. Sametband M, Kalt I, Gedanken A, Sarid R. Herpes simplex virus type-1 attachment inhibition by functionalized graphene oxide. ACS Appl Mater Interfaces. 2014;6:1228-35.

35. Donskyi IS, Azab W, Cuellar-Camacho JL, Guday G, Lippitz A, Unger WES, Osterrieder K, Adeli M, Haag R. Functionalized nanographene sheets with high antiviral activity through synergistic electrostatic and hydrophobic interactions. Nanoscale. 2019;11:15804-9.

36. Shen MX, Ma N, Li MK, Liu YY, Chen T, Wei F, Liu DY, Hou W, Xiong HR, Yang ZO. Antiviral Properties of $R$. tanguticum Nanoparticles on Herpes Simplex Virus Type I In Vitro and In Vivo. Front Pharmacol. 2019;10:959.

37. Tahara K, Kobayashi M, Yoshida S, Onodera R, Inoue N, Takeuchi H. Effects of cationic liposomes with stearylamine against virus infection. Int J Pharm. 2018;543:311-7.

38. Grumezescu AM. Antimicrobial Nanoarchitectonics: From Synthesis to Applications. $11^{\text {th }}$ ed. Chapter 14. Elsevier Science; 2017.

39. Luganini A, Nicoletto SF, Pizzuto L, Pirri G, Giuliani A, Landolfo S, Gribaudo G. Inhibition of herpes simplex virus type 1 and type 2 infections by peptidederivatized dendrimers. Antimicrob. Agents Chemother. 2011;55:3231-9.

40. Tarallo R, Carberry TP, Falanga A, Vitiello M, Galdiero S, Galdiero M, Weck $M$. Dendrimers functionalized with membrane-interacting peptides for viral inhibition. Int J Nanomedicine. 2013;8:521-34.

41. Chamundeeswari $M, J$ Jeslin J, Verma ML. Nanocarriers for drug delivery applications. Environ Chem Lett. 2019;17:849-65.

42. Kondel R, Shafiq N, Kaur IP, Singh MP, Pandey AK, Ratho RK, Malhotra S. Effect of Acyclovir Solid Lipid Nanoparticles for the Treatment of Herpes Simplex Virus (HSV) Infection in an Animal Model of HSV-1 Infection. Pharm Nanotechnol. 2019;7:389-403.
43. Muzzalupo R, Tavano L. Niosomal drug delivery for transdermal targeting: recent advances. Research and Reports in Transdermal Drug Delivery. 2015;4:23-33.

44. Akbarzadeh A, Rezaei-Sadabady R, Davaran S, Joo SW, Zarghami N, Hanifehpour Y, Samiei M, Kouhi M, Nejati-Koshki K. Liposome: classification, preparation, and applications. Nanoscale Res Lett. 2013;8:102.

45. Mukherjee B, Patra B, Layek B, Mukherjee A. Sustained release of acyclovir from nano-liposomes and nano-niosomes: an in vitro study. Int J Nanomedicine. 2007;2:213-25.

46. Mirzaei P, Monavari SH, Dadashzadeh S, Ebrahimi SA, Bolouri B, Haeri A. Preparation and Evaluation of the Antiviral Activity of Avyclovir Loaded Nano-Niosomes Against Herpes Simplex Virus Type 1. Pharmacophore. 2014;5:483-93.

47. Salem HF, Tamam SM, Lotayef SM. Biodegradable Liposomes for AcyclovirGold Nanoparticles As an Efficient Carrierfor Enhanced Topical Delivery. Int J Pharm Pharm Sci. 2017;9:60.

48. Rizwanullah ZS, Mir SZ, Amin S. Bilosomes nanocarriers for improved oral bioavailability of acyclovir: A complete characterization through in vitro, ex vivo and in vivo assessment. J Drug Deliv Sci Tec. 2020; 57:101634.

49. Donalisio M, Leone F, Civra A, Spagnolo R, Ozer O, Lembo D, Cavalli R. Acyclovir-Loaded Chitosan Nanospheres from Nano-Emulsion Templating for the Topical Treatment of Herpesviruses Infections. Pharmaceutics. 2018;10:46.

50. Foroozandeh P, Aziz AA. Insight into Cellular Uptake and Intracellular Trafficking of Nanoparticles. Nanoscale Res Lett. 2018;13:339. 